\title{
Soil organic carbon management for sustainable land use in Sudano-Sahelian West Africa
}

\author{
A. Bationo ${ }^{1, *} \&$ A. Buerkert ${ }^{2}$ \\ ${ }^{1}$ Tropical Soil Biology and Fertility Programme, P.O. Box 30592, Nairobi, Kenya; ${ }^{2}$ Institute of crop \\ science, university of Kassel, Steinstr. 19, D-37213 Witzenhausen, Germany; *Author for correspondence \\ (e-mail:a.bationo@cgiar.org)
}

Received 19 August 1999; accepted in revised form 3 February 2001

Key words: clay content, crop residues, GIS, millet, mineral fertilisers, soil erosion, sustainability

\begin{abstract}
Judged by their negative nutrient balances, low soil cover and low productivity, the predominant agro-pastoral farming systems in the Sudano-Sahelian zone of West Africa are highly unsustainable for crop production intensification. With kaolinite as the main clay type, the cation exchange capacity of the soils in this region, often less than $1 \mathrm{cmol}_{\mathrm{c}} \mathrm{kg}^{-1}$ soil, depends heavily on the organic carbon (Corg) content. However, due to low carbon sequestration and to the microbe, termite and temperature-induced rapid turnover rates of organic material in the present land-use systems, Corg contents of the topsoil are very low, ranging between 1 and $8 \mathrm{~g} \mathrm{~kg}^{-1}$ in most soils. For sustainable food production, the availability of phosphorus $(\mathrm{P})$ and nitrogen $(\mathrm{N})$ has to be increased considerably in combination with an improvement in soil physical properties. Therefore, the adoption of innovative management options that help to stop or even reverse the decline in Corg typically observed after cultivating bush or rangeland is of utmost importance. To maintain food production for a rapidly growing population, targeted applications of mineral fertilisers and the effective recycling of organic amendments as crop residues and manure are essential. Any increase in soil cover has large effects in reducing topsoil erosion by wind and water and favours the accumulation of wind-blown dust high in bases which in turn improves $\mathrm{P}$ availability. In the future decision support systems, based on GIS, modelling and simulation should be used to combine (i) available fertiliser response data from on-station and on-farm research, (ii) results on soil productivity restoration with the application of mineral and organic amendments and (iii) our present understanding of the cause-effect relationships governing the prevailing soil degradation processes. This will help to predict the effectiveness of regionally differentiated soil fertility management approaches to maintain or even increase soil Corg levels.
\end{abstract}

\section{Introduction}

The Sudano-Sahelian zone of West Africa (SSWA) is the home of the world's poorest people, $90 \%$ of whom live in villages and gain their livelihood from subsistence agriculture. The ongoing predominance of subsistence agriculture with limited access to market, and with very low levels of external inputs of mineral fertilisers and highly negative nutrient balances (Stoorvogel and Smaling, 1990) leads to a stagnation of agricultural productivity. However, the rather general lack of adoption of so called 'green revolution technologies' by farmers in SSWA is not only the con- sequence of inappropriate policies that favour urban populations at the expense of the rural sector but also of a very particular agricultural resource base.

Poor native soil fertility, low and erratic rainfall, high soil and air temperatures, surface crusting, low water-holding capacities and recurrent droughts are the main abiotic constraints to plant growth. Across the cultivated zones average rainfall varies from 300 to $800 \mathrm{~mm}$ and the ratio of annual rainfall to annual potential evapo-transpiration from 0.20 to 0.65 . This zone is represented as the semiarid zones in Figure 1. Annual potential evapo-transpiration in SSWA is often over $1000 \mathrm{~mm}$, higher than in Tropical Australia at 


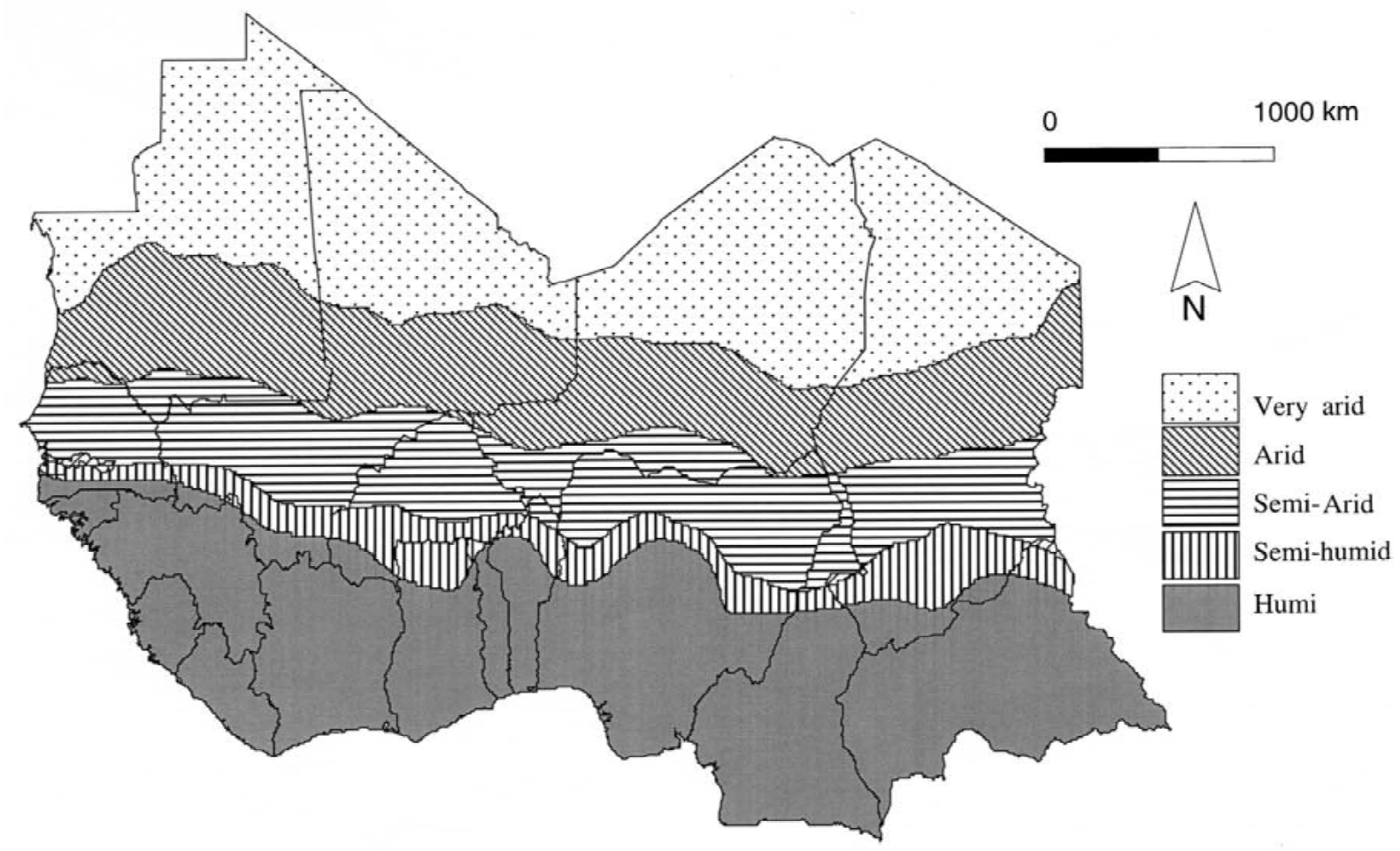

Figure 1. Agro-climatic zones in Sudano Sahelian West Africa (SSWA).

the same total amount of rainfall (Breman, 1998). The aridity of the climate means that the contribution of perennial species to the annual plant production, even in the case of undisturbed vegetation, is lower than elsewhere in the world at the same amount of annual rainfall. High soil temperatures, often exceeding 45 ${ }^{\circ} \mathrm{C}$, can prevent crop establishment. Early season sand blasting caused by wind erosion further hampers seedling growth and rapid soil coverage with plants. Still, in the Sudano-Sahelian area, above $300 \mathrm{~mm}$ annual precipitation, primary and crop production are more limited by nutrients, phosphorus $(\mathrm{P})$ before nitrogen $(\mathrm{N})$, than by water or the adverse bio-physical conditions (Penning de Vries and Djitèye, 1982). The dominance of nutrient limitation over water is such that the vegetation uses only $10-15 \%$ of the average rainfall (Breman and de Ridder, 1991). The rest is lost by evaporation, run-off and leaching. The breakdown of these systems with population growth requires alternative approaches at higher levels of external inputs to increase the productivity of agricultural land. The effects of the application of organic materials such as crop residues (CR) and manure on the recycling of plant nutrients, on soil coverage and soil erosion and on the overall $\mathrm{C}$ balance of the agro-pastoral systems
Table 1. Correlation $(r)$ between selected soil $(0-20 \mathrm{~cm})$ fertility parameters and average annual rainfall $(n=31)$

\begin{tabular}{lllllll}
\hline & $\mathrm{Ca}$ & $\mathrm{CEC}$ & $\mathrm{Corg}$ & Total N & Clay & Rainfall \\
\hline $\mathrm{pH} \mathrm{KCl}$ & $0.62^{* * * a}$ & $0.64^{* * *}$ & $0.65^{* * *}$ & $0.62^{* * *}$ & -0.02 & $0.25^{* *}$ \\
$\mathrm{Ca}$ & & $0.98^{* * *}$ & $0.88^{* * *}$ & $0.92^{* * *}$ & $0.36^{* * *}$ & $0.31^{* * *}$ \\
$\mathrm{CEC}$ & & & $0.86^{* * *}$ & $0.91^{* * *}$ & $0.40^{* * *}$ & $0.36^{* * *}$ \\
Corg & & & & $0.97^{* * *}$ & $0.46^{* * *}$ & $0.42^{* * *}$ \\
Total N & & & & $0.44^{* * *}$ & $0.34^{* * *}$ \\
Clay & & & & & & $0.40^{* * *}$ \\
\hline
\end{tabular}

** and ${ }^{* * *}$ indicate statistical significance at the 0.05 and 0.001 level, respectively.

Source: Manu et al., 1991.

are well documented (Bationo et al., 1995; Buerkert et al., 1996; Padwick, 1983). However, much less is known about the effects of management practices on the Corg status of West African soils and how these may differ with soil type and climate. To this end, this paper will first discuss the status of Corg in the soils of the region and its annual losses in different management systems. Subsequently it will address the effects of organic amendments on soil properties and soil conservation. The last section will conclude by suggestions avenues for action and future research to contribute to a more sustainable land-use in this zone. 


\section{Role of soil organic carbon and its fate as affected by management practises}

The concentration of organic carbon in the topsoil reported to average $12 \mathrm{mg} \mathrm{kg}^{-1}$ for the forest zone, 7 $\mathrm{mg} \mathrm{kg}{ }^{-1}$ for the Guinean zone, $4 \mathrm{mg} \mathrm{kg}^{-1}$ in the Sudanian zone and $2 \mathrm{mg} \mathrm{kg}^{-1}$ for the Sahel under the conditions of an undisturbed climax vegetation (Breman, 1998) is of utmost importance for the maintenance of soil productivity and was traditionally guaranteed through regular fallow periods. The soils in the Sudano-Sahelian zone are inherently low in Corg. These reflect the low shoot and root growth of crops and natural vegetation but also the rapid turnover rates of organic material with high soil temperature and microfauna, particularly termites. In a survey of 31 millet producing soils, Manu et al. (1991) found an average soil Corg content of $7.6 \mathrm{~g} \mathrm{~kg}^{-1}$ with a range from 0.8 to $29.4 \mathrm{~g} \mathrm{~kg}^{-1}$. The data also showed that these Corg contents were highly correlated with total $\mathrm{N}$ ( $r=$ 0.97; Table 1) which indicates that in the predominant agro-pastoral systems without the application of mineral $\mathrm{N}$ fertilisers, $\mathrm{N}$ nutrition of crops largely depend on the maintenance of soil Corg levels. The effect of rainfall on turnover rates of Corg through higher biomass production, coupled with higher decay rates is reflected in the statistically significant but absolutely low correlation between rainfall and Corg $(r=0.42)$.

The importance of soil textural (clay and silt) properties for the Corg content of soils was stressed repeatedly as clays are an important component in the direct stabilisation of organic molecules and microorganisms (Amato and Ladd, 1992; Greenland and Nye, 1959; Feller et al., 1992). Thus, Feller et al. (1992) reported that independently of climatic variations such as precipitation, temperature and duration of the dry season Corg increased between 600 and $3000 \mathrm{~mm}$ annual rainfall with the clay and silt contents of low activity clay soils. Therefore, small variations in topsoil texture at the field or watershed level could have large effects on Corg. In this context, a survey of West African soils (Manu et al., 1991) indicated that for the soils investigated cation exchange capacity (CEC) depended more directly on Corg $(r=0.86)$ than on the soils' clay content $(r=0.46)$. De Ridder and Van Keulen (1990) found that a difference of $1 \mathrm{~g} \mathrm{~kg}^{-1}$ in Corg resulted in a difference of $0.25 \mathrm{cmol} \mathrm{kg}^{-1}$ for soil CEC. As a key determinant of soil productivity the maintenance of Corg levels must therefore be an important goal of farmers and researchers.
There is much evidence for a rapid decline of Corg levels with continuous cultivation of crops in SSWA (Bationo et al., 1995). For the sandy soils, average annual losses in Corg, often expressed by the $k$-value (calculated as the percentage of organic carbon lost per year), may be as high as $4.7 \%$, whereas for sandy loam soils, reported losses seem much lower, with an average of $2 \%$ much lower (Pieri, 1989; Table 2). Topsoil erosion may lead to significant increases in annual Corg losses such as from $2 \%$ to $6.3 \%$ at the Centre de Formation des Jeunes Agriculteurs (CFJA) in Burkina Faso (Table 2). However, such declines are site-specific and heavily depend on management practises such as the choice of the cropping system, soil tillage and the application of mineral and organic soil amendments. Data from Chad show that crop rotation and fallow management can minimise Corg losses. Thus, $k$-values in cotton-cereal rotations were $2.4 \%$, lower than the $2.8 \%$ continuous cotton system. Also four years of fallow after 16 years of cultivation had led to large increases in Corg and a reduction of annual Corg losses to $0.5 \%$. Data from a rotation trial at Sadoré in the Sahel revealed significant effects of crop rotation on soil Corg contents. After five years, Corg levels were $2.8 \mathrm{~g} \mathrm{~kg}^{-1}$ in millet/cowpea intercrop plots that were rotated with pure cowpea compared to continuous millet plots with $2.2 \mathrm{~g} \mathrm{Corg} \mathrm{kg}^{-1}$ (Bationo, unpublished data). The higher Corg level in the cowpea system was at least partly due to the falling of leaves from the legume crop.

At Nioro-du-Rip in Senegal without mineral fertiliser application, soil tillage increased annual the rate of annual Corg losses $\mathrm{k}$ from $3.8 \%$ to $5.2 \%$ (Table 2), whereas with mineral fertilisers at Sefa, Corg values increased from $3.8 \mathrm{~g} \mathrm{~kg}^{-1}$ with manual tillage to 64 $\mathrm{mg} \mathrm{kg}^{-1}$ with deep tillage (Pieri, 1989). The effects of mineral fertiliser application on Corg seem to depend on the type of fertiliser used. While annual $\mathrm{N}$ application at $100 \mathrm{~kg} \mathrm{ha}^{-1}$ was found to cause an $\mathrm{N}$ flush from decomposing organic matter of between 300 and 400 $\mathrm{kg} \mathrm{N} \mathrm{ha}^{-1}$ through an increase in biological activity, regular NPK applications were reported to reduce the depletion of Corg (Pieri, 1989). Similarly at Niorodu-Rip in Senegal, annual Corg losses declined from $5.2 \%$ without NPK to $3.9 \%$ with NPK (Table 2). On the other hand fertiliser effects on crop growth may also be affected by a soil's Corg level. Berger et al. (1987) reported from the Northern Guinean zone that crop responses to chemical fertilisers ceased below 3.5 $\mathrm{mg}$ Corg kg ${ }^{-1}$. On sandy Sahelian soils, however, Bationo et al. (1998) reported a very strong response to 
Table 2. Annual loss rates of soil organic carbon measured at selected research stations in the SSWA

\begin{tabular}{|c|c|c|c|c|c|}
\hline \multirow[t]{2}{*}{$\begin{array}{l}\text { Place and } \\
\text { source }\end{array}$} & \multirow[t]{2}{*}{$\begin{array}{l}\text { Dominant cultural } \\
\text { succession }\end{array}$} & \multirow[t]{2}{*}{ Observations } & \multirow{2}{*}{$\begin{array}{l}\text { Clay }+ \\
\text { Silt }(\%) \\
(0-0.2 \mathrm{~m})\end{array}$} & \multicolumn{2}{|c|}{$\begin{array}{l}\text { Annual loss rates of soil } \\
\text { organic carbon }(k)\end{array}$} \\
\hline & & & & $\begin{array}{l}\text { Number of years } \\
\text { of measurement }\end{array}$ & $k(\%)$ \\
\hline \multicolumn{2}{|l|}{ Burkina Faso } & \multicolumn{4}{|l|}{ With tillage } \\
\hline \multirow{4}{*}{$\begin{array}{l}\text { Saria, INERA- } \\
\text { IRAT }\end{array}$} & Sorghum monoculture & Without fertiliser & 12 & 10 & 1.5 \\
\hline & Sorghum monoculture & Low fertilizser (lf) & 12 & 10 & 1.9 \\
\hline & Sorghum monoculture & high fertiliser (hf) & 12 & 10 & 2.6 \\
\hline & Sorghum monoculture & If + crop residues & 12 & 10 & 2.2 \\
\hline $\begin{array}{l}\text { CFJA, INERA- } \\
\text { IRCT }\end{array}$ & Cotton-cereals & Eroded watershed & 19 & 15 & 6.3 \\
\hline Senegal & & With tillage & & & \\
\hline Bambey, & Millet-groundnut & Without fertiliser & 3 & 5 & 7.0 \\
\hline \multirow[t]{2}{*}{ ISRA-IRAT } & Millet-groundnut & With fertiliser & 3 & 5 & 4.3 \\
\hline & Millet-groundnut & Fertiliser + straw & 3 & 5 & 6.0 \\
\hline $\begin{array}{l}\text { Bambey, } \\
\text { ISRA-IRAT }\end{array}$ & Millet monoculture & $\begin{array}{l}\text { with PK fertiliser + } \\
\text { tillage }\end{array}$ & 4 & 3 & 4.6 \\
\hline Nioro-du-Rip, & Cereal-leguminous & F0T0 & 11 & 17 & 3.8 \\
\hline \multirow[t]{4}{*}{ IRAT-ISRA } & Cereal-leguminous & F0T2 & 11 & 17 & 5.2 \\
\hline & Cereal-leguminous & F2T0 & 11 & 17 & 3.2 \\
\hline & Cereal-leguminous & $\mathrm{F} 2 \mathrm{~T} 2$ & 11 & 17 & 3.9 \\
\hline & Cereal-leguminous & F1T1 & 11 & 17 & 4.7 \\
\hline Chad & & $\begin{array}{l}\text { With tillage, } \\
\text { high fertility soil }\end{array}$ & & & \\
\hline Bebedjia, & Cotton monoculture & & 11 & 20 & 2.8 \\
\hline \multirow[t]{3}{*}{ IRCT-IRA } & Cotton - cereals & & & 20 & 2.4 \\
\hline & +2 years fallow & & & 20 & 1.2 \\
\hline & +4 years fallow & & & 20 & 0.5 \\
\hline
\end{tabular}

$\mathrm{F} 0=$ no fertiliser, $\mathrm{F} 1=200 \mathrm{~kg} \mathrm{ha}^{-1}$ of NPK fertiliser, $\mathrm{F} 2=400 \mathrm{~kg} \mathrm{ha}^{-1}$ of NPK fertiliser + Taiba phosphate rock, $\mathrm{T} 0=$ manual tillage, $\mathrm{T} 1=$ light tillage, $\mathrm{T} 2=$ heavy tillage.

Source: Pieri, 1989.

mineral fertilisers with Corg contents as low as $1.7 \mathrm{mg}$ $\mathrm{kg}^{-1}$. There is still not a clear scientific explanation for this discrepancy.

The effects of surface mulched cereal stover (CR) on Corg levels are contradictory (Bationo et al., 1995). Through the stimulation of microbial activity, CR application can lead to a depletion of Corg. At a Sahelian site, soil respiration at millet harvest was found to be $2.7 \mathrm{mg} \mathrm{C} \mathrm{kg}^{-1} \mathrm{~d}^{-1}$ in plots mulched with $4 \mathrm{t}$ $\mathrm{CR} \mathrm{ha}{ }^{-1}$ compared to $1.5 \mathrm{mg} \mathrm{C} \mathrm{kg}^{-1} \mathrm{~d}^{-1}$ in unmulched control plots. Average Corg mineralisation was more than twice as high in mulched plots than in unmulched plots (Bationo et al., 1999). At Saria in Burkina Faso, annual Corg losses increased from 1.9\% without CR application to $2.2 \%$ with $\mathrm{CR}$ mulching.
Similar increases in Corg losses were also reported from Bambey in Senegal (Table 2).

Nevertheless, these data are challenged by the results of a mulching experiment conducted from 1995 to 1998 at eight sites in SSWA from 510 to $1300 \mathrm{~mm}$ annual average rainfall and clay contents between $2 \%$ and $20 \%$. They showed that with yearly CR mulching at $2000 \mathrm{~kg} \mathrm{CR} \mathrm{ha}^{-1}$ Corg levels declined much less than at a mulch rate of $500 \mathrm{~kg} \mathrm{CR} \mathrm{ha}^{-1}$ (Buerkert et al., 1999a).

Effects of crop residues and manure on soil productivity, fertiliser use efficiency and soil properties in a long term crop residue and fertilizers management trials conducted at Sadore (Niger) from 1984 to 1996. A slow-down of Corg from pre-cultivation levels has been found. In this trial CR mulch at $2 \mathrm{t} \mathrm{ha}^{-1}$ and 


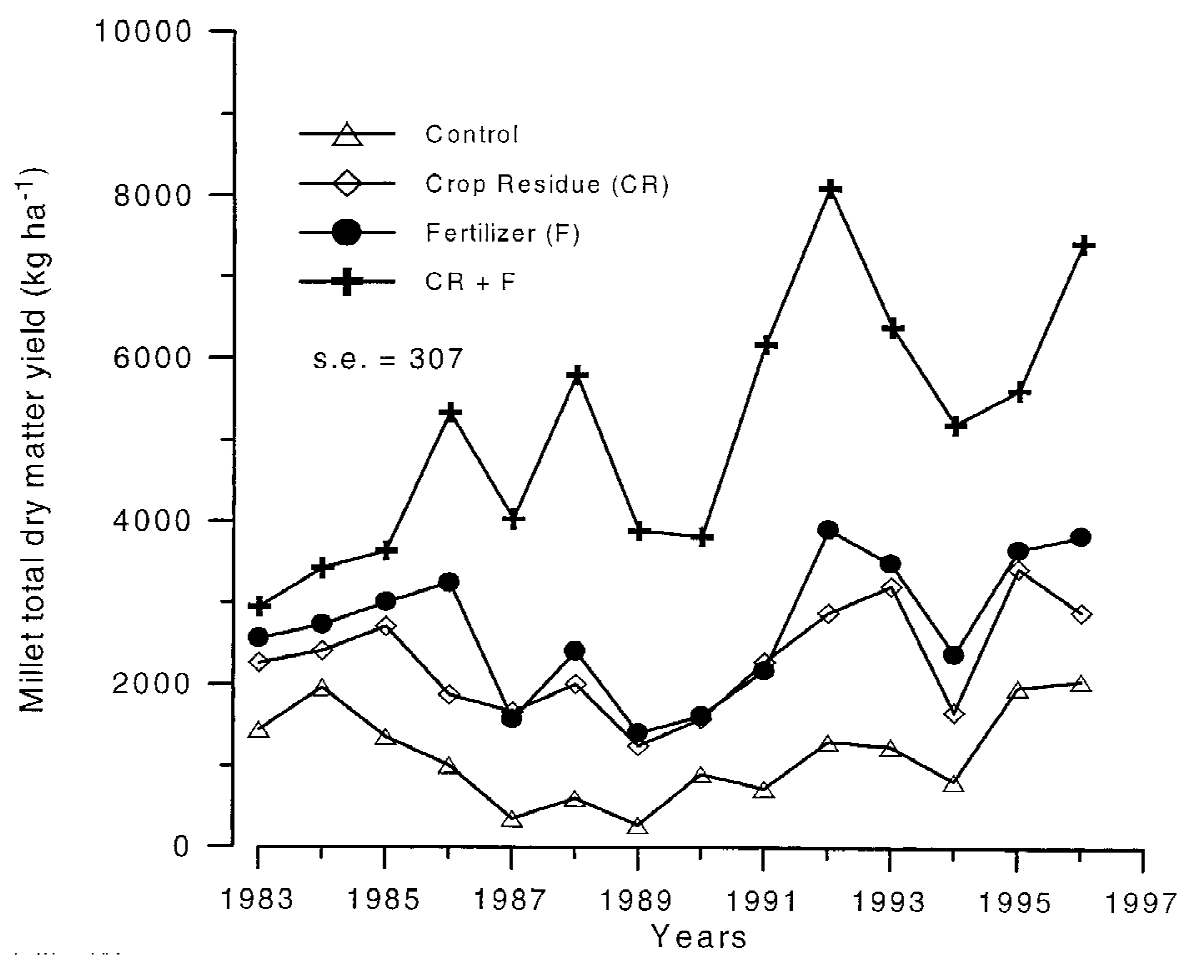

Figure 2. Pearl millet total dry matter yield as affected by different management practices over years. Source: Bationo et al. (1998).

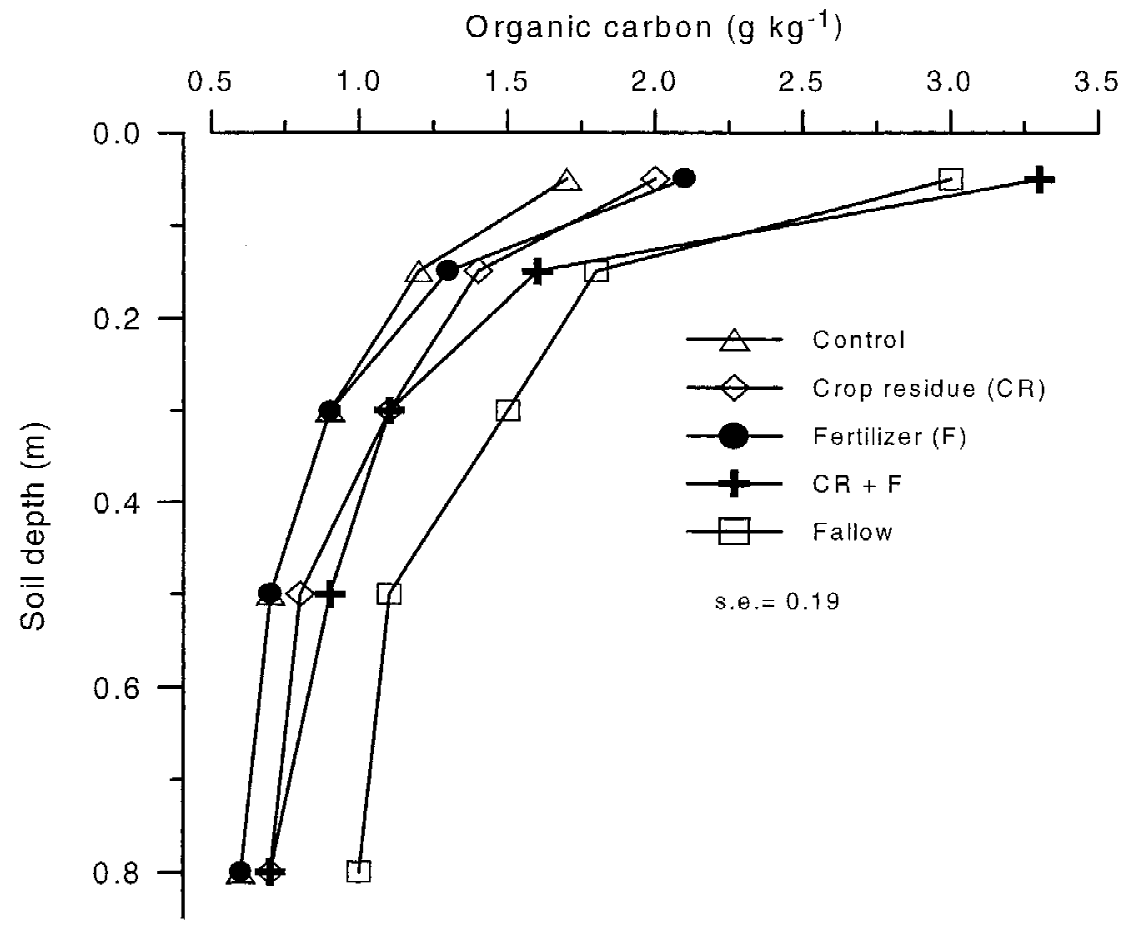

Figure 3. Soil organic carbon (Corg) as affected by soil depth and management practices. Sadoré, Niger, rainy season, 1996. 
Table 3. Increase in incremental millet grain and stover yield due to fertiliser application

\begin{tabular}{|c|c|c|c|c|}
\hline \multirow[t]{3}{*}{ Zone } & \multirow[t]{3}{*}{ Year } & \multirow[t]{3}{*}{ Treatment } & \multicolumn{2}{|c|}{ Fertiliser effect } \\
\hline & & & Grain & Stover \\
\hline & & & \multicolumn{2}{|c|}{$\mathrm{kg}$ per $\mathrm{kg} \mathrm{P}$ appliec } \\
\hline \multirow[t]{12}{*}{ Sahelian zone (Sadoré) } & 1983 & $\mathrm{CR}$ & - & - \\
\hline & & Fertiliser & $59^{1}$ & NA \\
\hline & & $\mathrm{CR}+$ Fertiliser & $72^{2}$ & NA \\
\hline & 1984 & $\mathrm{CR}$ & - & - \\
\hline & & Fertiliser & 34 & 21 \\
\hline & & $\mathrm{CR}+$ Fertiliser & 14 & 31 \\
\hline & 1985 & $\mathrm{CR}$ & - & - \\
\hline & & Fertiliser & 67 & 188 \\
\hline & & $\mathrm{CR}+$ Fertiliser & 137 & 427 \\
\hline & 1986 & $\mathrm{CR}$ & - & - \\
\hline & & Fertiliser & 57 & 184 \\
\hline & & $\mathrm{CR}+$ Fertiliser & 112 & 359 \\
\hline \multirow[t]{9}{*}{ Sudanian zone (Tara) } & 1990 & $\mathrm{CR}$ & - & - \\
\hline & & Fertiliser & 81 & 103 \\
\hline & & $\mathrm{CR}+$ Fertiliser & 87 & 124 \\
\hline & 1991 & $\mathrm{CR}$ & - & - \\
\hline & & Fertiliser & 51 & 108 \\
\hline & & $\mathrm{CR}+$ Fertiliser & 44 & 115 \\
\hline & 1992 & $\mathrm{CR}$ & - & - \\
\hline & & Fertiliser & 40 & 83 \\
\hline & & $\mathrm{CR}+$ Fertiliser & 40 & 90 \\
\hline
\end{tabular}

1. Calculated as (yield fertiliser - yield control) / $\mathrm{P}$ applied.

2. Calculated as (yield CR + fertiliser - yield control) / P applied.

$\mathrm{NA}=$ not available.

Source: Bationo et al., 1995

the annual application of $13 \mathrm{~kg} \mathrm{P} \mathrm{ha}^{-1}$ as SSP plus $30 \mathrm{~kg} \mathrm{~N} \mathrm{ha}^{-1}$ as CAN led to similar TDM increases and to large additive effects (Figure 2). Levels of Corg were with $1.7 \mathrm{~g} \mathrm{~kg}^{-1}$ at $0.1 \mathrm{~m}$ lowest in unmulched control plots and with $3.3 \mathrm{~g} \mathrm{~kg}^{-1}$ highest in the topsoil of plots with the combined application of $4 \mathrm{t} \mathrm{CR} \mathrm{ha} \mathrm{ha}^{-1}$ and mineral fertilisers. However, even in plots with both amendments combined Corg levels were, except for the surface soil, lower than in an adjacent fallow (Figure 3).

Numerous research reports showed large crop yield increases as a consequence of organic amendments in the Sahelian zone of West Africa (Abdullahi and Lombin, 1978; Bationo et al., 1993, 1998; Evéquoz et al., 1998; Pieri, 1986, 1989). Bationo et al. (1995) reported from an experiment carried out in 1985 on a sandy soil at Sadoré, Niger that grain yield of pearl millet (Pennisetum glaucum L.) after a number of years had declined to only $160 \mathrm{~kg} \mathrm{ha}^{-1}$ in unmulched and unfertilised control plots. However, grain yields could be increased to $770 \mathrm{~kg} \mathrm{ha}^{-1}$ with a mulch application of $2 \mathrm{t} \mathrm{CR} \mathrm{ha}^{-1}$ and to $1030 \mathrm{~kg} \mathrm{ha}^{-1}$ with $13 \mathrm{~kg} \mathrm{P}$ as SSP plus $30 \mathrm{~kg} \mathrm{~N} \mathrm{ha}^{-1}$. The combination of CR and mineral fertilisers resulted in a grain yield of $1940 \mathrm{~kg} \mathrm{ha}^{-1}$. Comparative data of $\mathrm{P}$ fertiliser use efficiency (FUE) with and without CR mulch application in the Sahel and the Sudanian zone underline the additive effects of both soil amendments (Table 3).

For the Sudanian zone, all available reports show a much smaller or even negative effect of the same rate of CR mulch on crop yields (Bationo et al., 1995; Sedogo, 1993). These differences in CR effects on crop growth between the Sahelian and Sudanian zone of West Africa may at least be partially explained by the effects of CR mulch on soil chemical and physical properties. In the Sahel with its early season sand storms, CR have been shown to increase soil P availability (Kretzschmar et al., 1991), cause better root growth (Hafner et al., 1993), improve potassium (K) nutrition (Rebafka et al., 1994), protect young seedlings against soil coverage during sand storms (Michels et al., 1995), increase water availability (Buerkert et al., 1999b), and reduce soil surface resistance by $65 \%$ (Buerkert and Stern, 1995) and topsoil temperature by over $4{ }^{\circ} \mathrm{C}$ (Buerkert et al., 1999b). In the Sudanian zone, in contrast, with its lower overall temperatures, higher rainfall, heavier soils and more rapid decomposition rates of organic materials, these effects of mulching on soil chemical properties have been found to be much weaker (Buerkert et al., 1999a).

The effects of mineral fertiliser application on $\mathrm{pH}$, exchangeable bases and $\mathrm{P}$ sorption seem, at least on the weakly buffered Sahelian soils, too strongly depend on $\mathrm{CR}$ recycling. Without $\mathrm{CR}$ mulching $\mathrm{pH}$ levels in the topsoil of plots to which $\mathrm{N}$ and $\mathrm{P}$ were applied over 14 years were considerably lower than unmulched control plots. The increased mulch material produced in plots with mineral fertilisers led, if recycled, to a large rise in respective $\mathrm{pH}$ values throughout the upper $0.3 \mathrm{~m}$ (Figure 4). Similar effects of mineral fertilisers and CR were also measured on exchangeable bases (Figure 5). This trial also revealed that maximum $\mathrm{P}$ sorption in the topsoil as calculated by the Langmuir equation, declined from $91 \mathrm{mg} \mathrm{P}$ $\mathrm{kg}^{-1}$ in unmulched control plots without $\mathrm{P}$ fertilisers to $54 \mathrm{mg} \mathrm{P} \mathrm{kg}$ with $\mathrm{P}$ application and to $37 \mathrm{mg} \mathrm{P}$ $\mathrm{kg}^{-1}$ with the additional application of $4 \mathrm{t} \mathrm{CR} \mathrm{ha}{ }^{-1}$ (Figure 6). From incubation studies under controlled conditions Kretzschmar et al. (1991) concluded that such increases in $\mathrm{P}$ availability after $\mathrm{CR}$ application were due to a complexation of iron and aluminium by organic acids.

On the nutrient poor West African soils, manure, the second farm-available soil amendment, can sub- 
Table 4. Results of manuring experiments at three sites in semi-arid West Africa

A: Manure only

\begin{tabular}{|c|c|c|c|c|}
\hline \multirow[t]{2}{*}{ Location } & \multirow{2}{*}{$\begin{array}{l}\text { Amount of } \\
\text { manure applied } \\
\left(\mathrm{t} \mathrm{ha}^{-1}\right)\end{array}$} & & \multicolumn{2}{|c|}{$\begin{array}{l}\text { Crop response }^{a} \\
\left(\mathrm{~kg} \text { of } \mathrm{DM} \mathrm{t}^{-1} \text { manure }\right)\end{array}$} \\
\hline & & Crop & Grain & Stover \\
\hline M'Pesoba, Mali & 10 & Sorghum & $35^{b}$ & n.s. \\
\hline Saria, Burkina Faso & 10 & Sorghum & 58 & n.s. \\
\hline \multirow[t]{2}{*}{ Sadore, Niger 1987} & 5 & Pearl millet & 38 & 178 \\
\hline & 20 & Pearl millet & 34 & 106 \\
\hline
\end{tabular}

B: Manure with inorganic fertiliser

\begin{tabular}{|c|c|c|c|c|c|}
\hline \multirow[t]{3}{*}{ Location } & \multicolumn{2}{|c|}{ Amount of } & \multirow{3}{*}{ Crop } & \multicolumn{2}{|c|}{ Crop response $^{a}$} \\
\hline & \multirow{2}{*}{$\begin{array}{l}\text { Manure } \\
\left(\mathrm{t} \mathrm{ha}^{-1}\right)\end{array}$} & \multirow{2}{*}{$\begin{array}{l}\text { Fertiliser } \\
\left(\mathrm{kg} \mathrm{ha}^{-1}\right)\end{array}$} & & \multicolumn{2}{|c|}{ (kg of $\mathrm{DM} \mathrm{t}^{-1}$ manure) } \\
\hline & & & & Grain & Stover \\
\hline M'Pesoba, Mali & 5 & NPK: $8-20-0$ & Sorghum & $90^{c}$ & n.s. \\
\hline Saria, Burkina Faso & 10 & Urea N: 60 & Sorghum & 80 & n.s. \\
\hline \multicolumn{6}{|l|}{ Sadoré, Niger } \\
\hline 1987 & 5 & SSP P: 8.7 & Pearl millet & 82 & 192 \\
\hline 1987 & 20 & SSP P: 17.5 & Pearl millet & 32 & 84 \\
\hline
\end{tabular}

${ }^{a}$ Responses were calculated at the reported treatment means for crop yields as: (treatment yield - control yield) / quantity of manure applied

${ }^{b}$ Response of sorghum planted in the second year of a 4-year rotation involving cotton-sorghum-groundnut-sorghum. Manure was applied in the first year.

${ }^{c}$ Estimated from visual intrapolation of graph.

n.s. = not specified.

Source: Williams et al., 1995

stantially enhance crop yields. For Niger, McIntire et al. (1992) reported grain yield increases between 15 and $86 \mathrm{~kg}$ for millet and between 14 and $27 \mathrm{~kg}$ for groundnut per ton of applied manure. Similar manure effects have been reported from other Sahelian countries (Table 4). However, given the large variation in the nutrient concentrations of the manure types applied, comparisons between results from different experiments should be made with great care (Table 5).

In general livestock can have significant effects on the maintenance of Corg levels in cropland, but cattle also is an important consumer and vector of organic materials and mineral nutrients from rangeland to manured fields. Recent data from village level studies the Sahel indicate that $46 \%$ of the grazed dry matter are either stored in the body mass of cattle and eventually transported to coastal slaughter houses or voided in the process of rumination and respiration (Buerkert and Hiernaux, 1998; Hiernaux et al., 1997).

\section{Adapted approaches to maintain organic matter and soil productivity}

In SSWA crop residues as surface mulch can play an important role in the maintenance of Corg levels and productivity of the prevailing acid soils through the recycling of mineral nutrients, increases in fertiliser use efficiency and a decrease in soil erosion effects on soil chemical, physical and biological properties. However, organic materials available for surface mulching are scarce given the low overall production levels of biomass in the region and their multiple competitive uses as fodder, construction materials and cooking fuel (Lamers and Feil, 1993). The quantities of CR found on-farm at the beginning of the rainy season range between 0 and $500 \mathrm{~kg} \mathrm{ha}^{-1}$. McIntire and Fussel (1986) reported that on farmers' fields in the Sahel average grain yields were $236 \mathrm{~kg} \mathrm{ha}^{-1}$ and mean CR yields barely reached $1300 \mathrm{~kg} \mathrm{ha}^{-1}$. In a study to determine CR availability at farm level Baidu-Forson (1995) reported that at Diantandou in Niger with a long-term annual rainfall $450 \mathrm{~mm}$, an average of 1200 $\mathrm{kg} \mathrm{ha}^{-1}$ of millet stover was produced at the end of the cropping season, but at the onset of the rains in 
$\mathrm{pH}(\mathrm{KCl})$

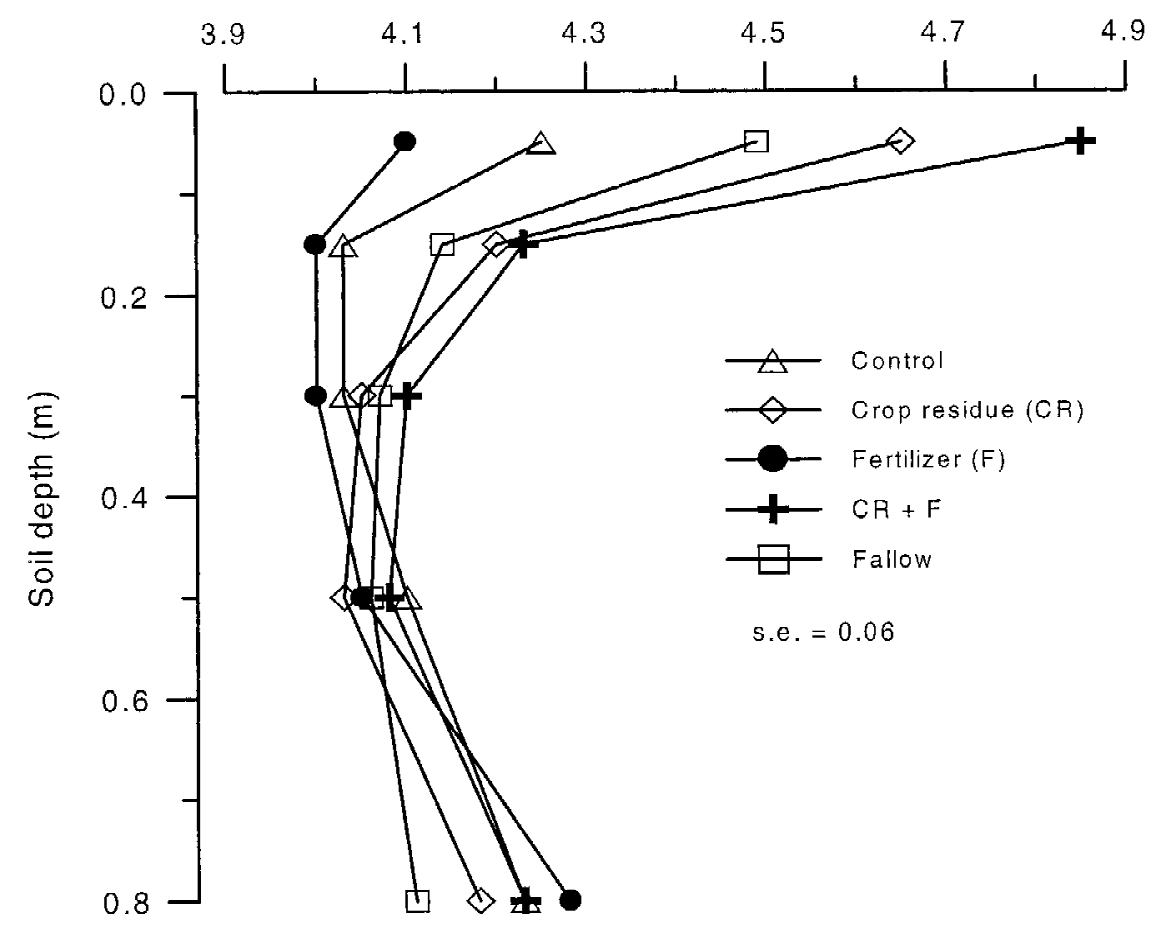

Figure 4. Soil pH as affected by soil depth and management practices. Sadoré, Niger, rainy season, 1996.

Table 5. Nutrient composition of manure at selected sites in semi-arid West Africa

\begin{tabular}{llll}
\hline \multirow{2}{*}{ Location and type of manure } & \multicolumn{4}{c}{ Nutrient composition (\%) } \\
\cline { 2 - 4 } & $\mathrm{N}$ & $\mathrm{P}$ & $\mathrm{K}$ \\
\hline Saria, Burkina Faso & & & \\
$\quad$ Farm yard manure & $1.5-2.5$ & $0.09-0.11$ & $1.3-3.7$ \\
$\quad$ Northern Burkina Faso & & & \\
$\quad$ Cattle manure & 1.28 & 0.11 & 0.46 \\
$\quad$ Small ruminant manure & 2.20 & 0.12 & 0.73 \\
$\quad$ Senegal & & & \\
$\quad$ Fresh cattle dung & 1.44 & 0.35 & 0.58 \\
$\quad$ Dry cattle dung & 0.89 & 0.13 & 0.25 \\
$\quad$ Niger & & & \\
$\quad$ Cattle manure & $1.2-1.7$ & $0.15-0.21$ & - \\
$\quad$ Sheep manure & $1.0-2.2$ & $0.13-0.27$ & - \\
\hline
\end{tabular}

Williams et al., 1995

the following year barely $250 \mathrm{~kg} \mathrm{ha}^{-1}$ remained for mulching. Powell et al. (1987) showed that at least $50 \%$ of these large on-farm disappearance rates of millet stover could be attributed to livestock grazing. This included a complete loss of millet leaves.
Animal manure has a similar role as residue mulching for the maintenance of soil productivity but depending on rangeland productivity, it will require between 10 and 40 ha of dry season grazing land and between 3 and 10 ha of rangeland of wet season grazing to maintain yields on one hectare of cropland (Fernandez-Rivera et al., 1995). The potential of manure to maintain soil Corg levels and sustain crop production is thus limited by the number of animals available and the size and quality of the rangeland.

At the systems level, the maintenance of Corg levels in the soils of SSWA will largely depend on an increase in $\mathrm{C}$ fixation by plants. Given the strong limitation of plant growth by the low availability of mineral nutrients, a yield-effective application of mineral fertilisers is crucial. It would not only allow large increases in crop production and the amount of byproducts but also to improve soil coverage by forage grasses and weeds. Both help to boost the overall productivity of the integrated crop-livestock systems with their multiple short-cuts in organic mater and nutrient cycles via animals. The use of locally available 'soft' rock phosphates suitable for direct application as soil amendment (McClellan and Notholt, 1986) may be 


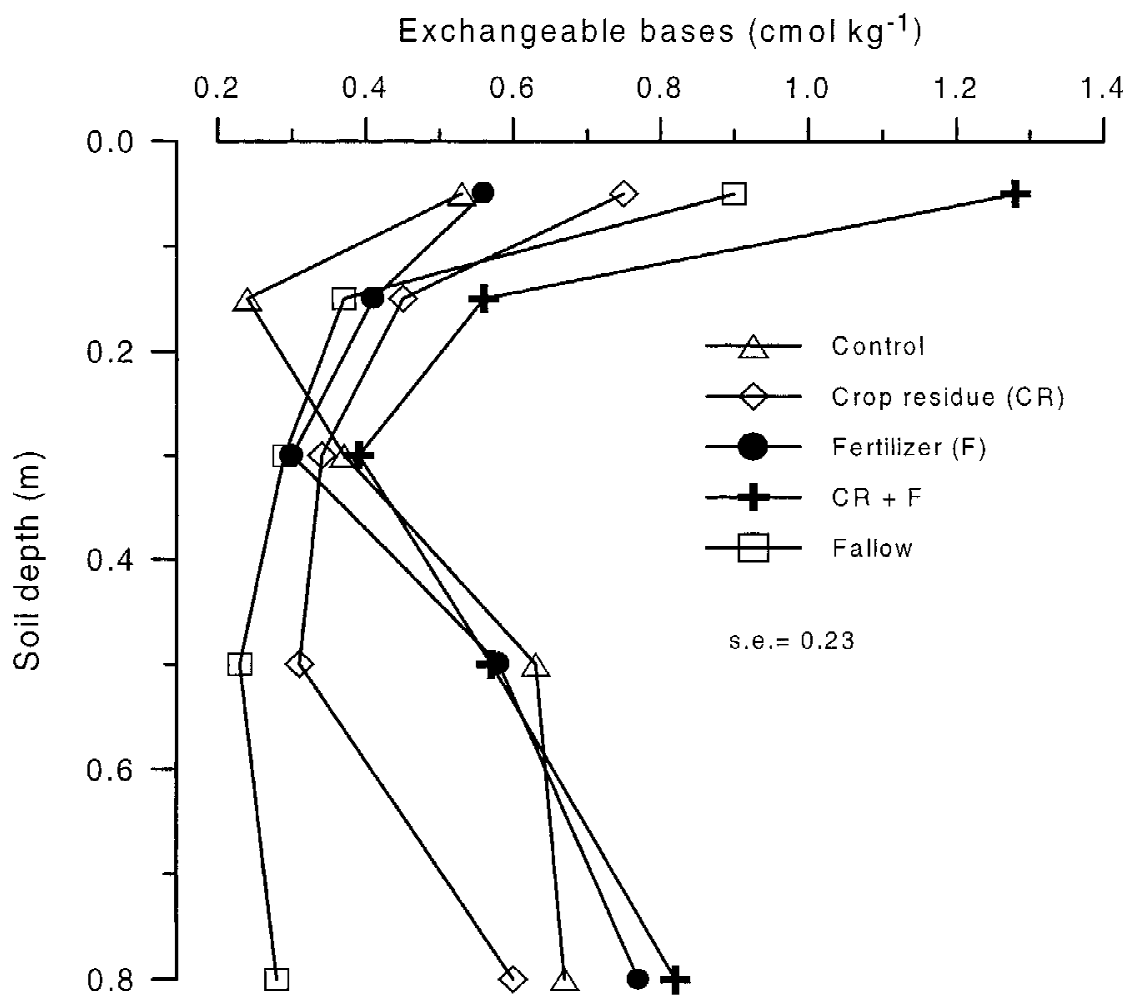

Figure 5. Exchangeable bases as affected by soil depth and management practices. Sadoré, Niger, rainy season, 1996.

Table 6. Effect of cattle and sheep dung and urine on pearl millet grain and total above-ground biomass, Sadore, Niger 1991

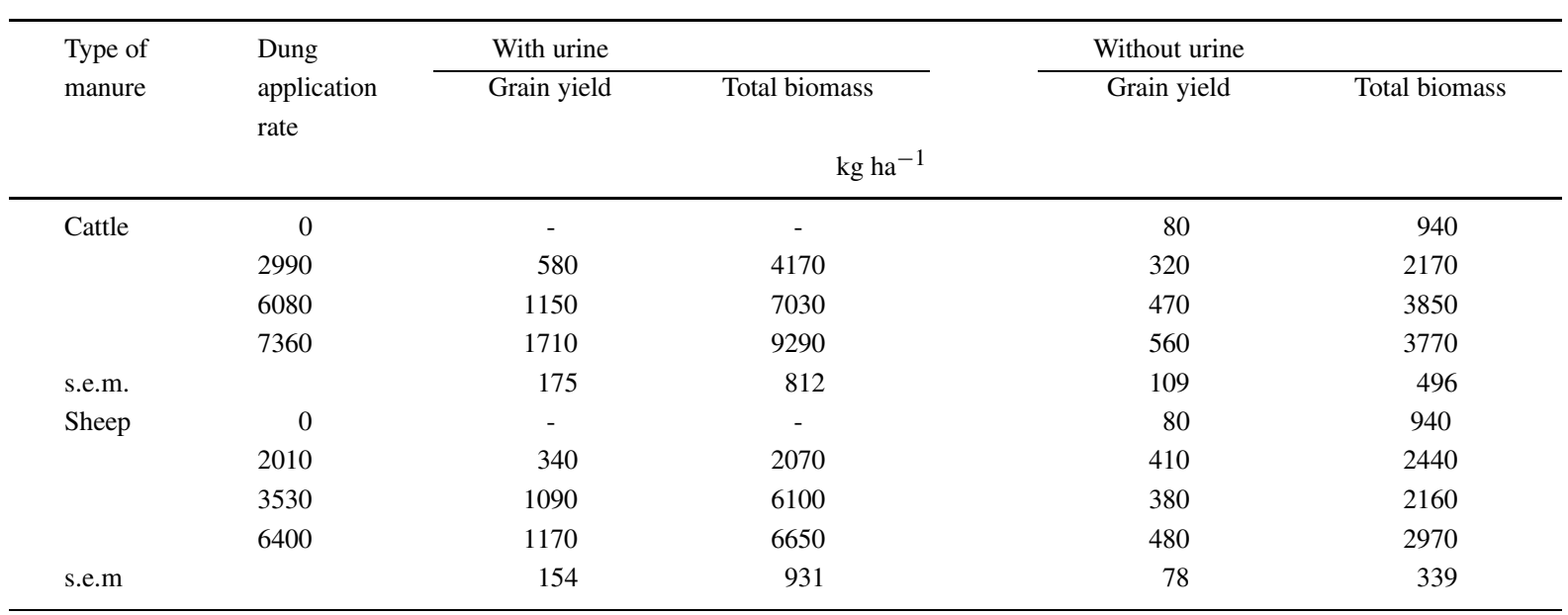

s.e.m. $=$ standard error of the mean.

Adapted from Powell et al., 1998

cost-effective with high rainfall and on sites with a soil $\mathrm{pH}<4.3$. Under those conditions Bationo et al. (1990) found 'Tahoua' (Niger) rock $76 \%$ as effective as SSP in increasing millet yields. A low cost alternative, the placement of $4 \mathrm{~kg} \mathrm{P} \mathrm{ha}{ }^{-1}$ as ground NPK
(15-15-15) with the seed at sowing or shortly thereafter was shown to cause average TDM increases in millet, sorghum, maize, cowpea and groundnut of $70 \%$ for cereals and $74 \%$ for legumes at eight sites in West Africa (Buerkert and Hiernaux, 1998). The same au- 


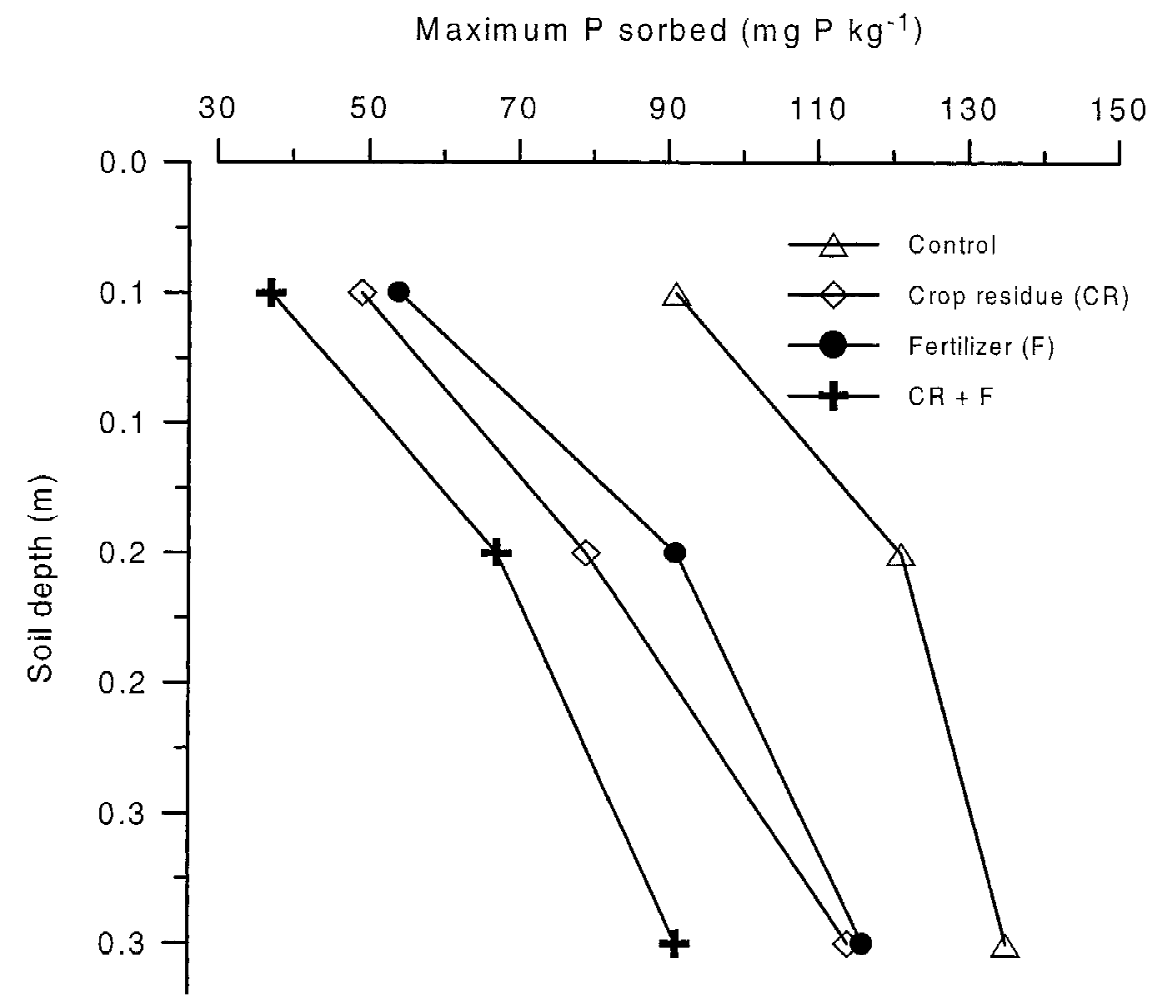

Figure 6. Maximum phosphorus sorbed as affected by soil depth and management practices, Sadoré, Niger, 1999.

thors also showed that after three years, TDM yields of cereals and legumes were doubled with either annual applications of $13 \mathrm{~kg} \mathrm{P} \mathrm{ha}^{-1}$ as SSP, or the combination of $39 \mathrm{~kg} \mathrm{P} \mathrm{ha}^{-1}$ applied once every three years as rock phosphate plus annual placed NPK application, or the combination of $130 \mathrm{~kg} \mathrm{P} \mathrm{ha}{ }^{-1}$ applied once every ten years as rock phosphate plus annual placed NPK application. Phosphorus use efficiency (PUE), expressed as average increase in total dry matter of crops per $\mathrm{kg}$ of $\mathrm{P}$ applied, was almost twice as high for placed NPK at $4 \mathrm{~kg} \mathrm{P} \mathrm{ha}^{-1}$ as for broadcast SSP at $13 \mathrm{~kg} \mathrm{P} \mathrm{ha}{ }^{-1}$. Lowest PUE values were obtained for rock phosphate treatments with or without NPK placement. In 1998, on-farm trials conducted with 250 farmers in three regions of Niger confirmed these yield increases with placed NPK application and showed that this simple technique was particularly attractive to farmers given a reduction in their investment costs by about $70 \%$ compared to broadcast application of SSP or NPK fertiliser at $13 \mathrm{~kg} \mathrm{P} \mathrm{ha}^{-1}$.

While it is clear that more basic research is still needed to increase our knowledge about the role and quality of organic matter in Sudano-Sahelian soils and how both are affected by management practices, the increased use of GIS based decision support systems should have an even higher priority. Together with more locally adapted crop growth simulation models, this would facilitate the definition of 'recommendation domains' for effective strategies to maintain Corg levels and subsequent soil productivity under the diverse agro-ecological conditions of SSWA. It would also allow to move away from the analysis of sitespecific results to a more detailed understanding of principles governing sustainable production systems. To be adopted at the farm level, however, any innovation must meet the multiple goals of local farmers, and particularly their desire to increase short-term income and reduce risk. This will remain a major challenge for researchers and policy-makers alike.

Future research needs to examine the cause-effect relationships governing the critical levels of organic matter at farm level in order to establish accurate critical levels for the different soil types and climate in the SSWA. Legumes component in mixed cropping systems to enhance soil fertility, boast subsequent crop yields, and provide high quality feed for livestock is a priority area that needs further investigation. Another important area for future research is the relationship 
between soil organic matter and soil physical characteristics, and the role of agro-forestry in soil organic carbon turnover. Since most of the data reported in this paper were collected from on-station experiments, future research needs to take into account farmers' practices and socio-economics conditions.

\section{Acknowledgements}

The authors wish to thank Dr. Barbara Buerkert for her help with graphs and tables.

\section{References}

Abdullahi A \& Lombin G (1978) Long-term fertility studies at Samaru-Nigeria: Comparative effectiveness of separate and combined applications of mineralizers and farmyard manure in maintaining soil productivity under continuous cultivation in the Savanna, Samaru, Samaru Miscellaneous Publication. No. 75, Zaria, Nigeria: Ahmadu Bello University

Amato M \& Ladd JN (1992) Decomposition of ${ }^{14} \mathrm{C}$ labelled glucose and legume material in soils: properties influencing the accumulation of organic residue-C and microbial biomass-C. Soil Biol Biochem 24: 455-464

Baidu-Forson J (1995) Determinants of the availability of adequate millet stover for mulching in the Sahel. J Sust Agric 5: 101-116

Bationo A, Chien SH, Henao J, Christianson BC \& Mokwunye AU (1990) Agronomic evaluation of two unacidulated and patially acidulated phosphate rocks indigenous to Niger. Soil Sci Soc Am J 54: 1772-1777

Bationo A, Christianson BC \& Klaij MC (1993) The effect of crop residue and fertiliser use on pearl millet yields in Niger. Fert Res 34: 251-258

Bationo A, Buerkert A, Sedogo MP, Christianson BC \& Mokwunye AU (1995) A critical review of crop residue use as soil amendment in the West African Semi-Arid Tropics. In: Powell JM, Fernandez-Rivera S, Williams TO \& Renard C (eds) Livestock and Sustainable Nutrient Cycling in Mixed Farming Systems of Sub-Saharan Africa, Vol. 2, pp 305-322.Technical Papers. Proceedings of an International Conference, 22-26 November 1993. International Livestock Centre for Africa (ILCA), Addis Ababa, Ethiopia

Bationo A, Lompo F \& Koala S (1998) Research on nutrient flows and balances in West Africa: State-of-the-art. In: Smaling EMA (ed) Nutrient Balances as Indicators of Production and Sustainability in Sub-Saharan African Agriculturale. Agric Eco Environ 71: 19-36

Bationo A, Wani S, Bielders C, Vlek PLG \& Mokwunye AU (1999) Crop residue management to enhance soil productivity and conservation in the Desert Margins of West Africa. Adv in Soil Sci (submitted)

Berger M, Belem PC, Dakoua D \& Hien V (1987) Le maintien de la fertilité des sols dans l'Ouest du Burkina Faso et la nécessité de l'association agriculture-élevage. Cot Fib Trop Vol XLII FASC 3: 210-211

Breman H \& de Ridder N (1991) Manuel sur les pâturages des pays sahéliens. ACCT, Paris/CTA, Wageningen / KARTHALA, Paris. $485 \mathrm{pp}$
Breman H (1998) Soil fertility improvement in Africa, a tool for or a by-product of sustainable production? Special Issue on Soil Fertility/African Fertiliser Market 11: 2-10

Buerkert A, Bationo A \& Dossa K (1999a) Mechanisms of residue mulch-induced cereals growth in West Africa. Soil Sci Soc Am J (accepted)

Buerkert A \& Hiernaux P (1998) Nutrients in the West African Sudano-Sahelian zone: losses, transfers and role of external inputs. J Plant Nutr Soil Sci 161: 365-383

Buerkert A, Michels K, Lamers JPA, Marschner H \& Bationo A (1996) Anti-erosive, soil physical and nutritional effects of crop residues. In: Buerkert B, Allison B E \& von Oppen M (eds) Wind Erosion in Niger. Implications and Control Measures in a Millet-Based Farming System, pp 123-138. Kluwer Academic Publishers, Dordrecht, The Netherlands

Buerkert A, Michels K \& Lamers JPA (1999b) Erosion processes in the West African Sahel and their effects on soil parameters and millet growth. Plant Soil (submitted)

Buerkert A \& Stern RD (1995) Crop residue and P application affect the spatial variability of non-destructively measured millet growth in the Sahel. Expl Agric 31: 429-449

De Ridder N \& van Keulen H (1990) Some aspects of the role of organic matter in sustainable intensified arable farming systems in the West African semi-arid tropics. Fert Res 26: 299-310

Evéquoz M, Soumana DK \& Yadji G (1998) Minéralisation du fumier, nutrition, croissance et rendement du mil planté dans des ouvrages anti-érosifs. In: Renard G, Neef A, Becker K \& von Oppen M (eds) Soil Fertility Management in West African Land Use Systems, pp 203-208 Niamey, Niger, 4-8 March 1997. Margraf Verlag, Weikersheim, Germany

Feller C, Brossard M \& Frossard E (1992) Caractérisation et dynamique de la matière organique dans quelques sols ferrugineux et ferrallitiques d'Afrique de l'Ouest. In: Tiessen H \& Frossard E (eds), pp 94-107. Phosphorus Cycles in Terrestrial and Aquatic Ecosystems. Proceedings of a workshop arranged by the Scientific Committee on Problems of the Environment (SCOPE) and the United Nations Environmental Programme (UNEP), 18-22, March 1991. Nairobi, Kenya

Fernandez-Rivera S Williams TO Hiernaux P \& Powell JM (1995) Livestock, feed, and manure availability for crop production in semi-arid West Africa. In: Powell JM, Fernandez-Rivera S, Williams TO \& Renard C (eds) Livestock and Sustainable Nutrient Cycling in Mixed Farming Systems of Sub-Saharan Africa, pp 149-170. Addis Ababa, Ethiopia: International Livestock Centre for Africa

Greenland DJ \& Nye PH (1959) Increases in the carbon and nitrogen contents of tropical soils under natural fallows. J Soil Sci 10: 284-299

Hafner H, Bley J, Bationo A, Martin P \& Marschner H (1993) Longterm nitrogen balance of pearl millet (Pennisetum glaucum L.) in an acid sandy soil of Niger. J Plant Nutr Soil Sci 256: 264-176

Hiernaux P, Fernández-Rivera S, Schlecht E, Turner MD \& Williams TO (1997) Livestock-mediated nutrient transfers in Sahelian agro-ecosystems. In: Renard G, Neef A, Becker K \& von Oppen $M$ (eds) Soil Fertility Management in West African Land Use Systems, pp 339-347. Proceedings of a Regional Workshop, University of Hohenheim, ICRISAT, INRAN, Niamey, Niger, 4-8 March 1997. Margraf Verlag, Weikersheim, Germany

Kretzschmar RM, Hafner H, Bationo A \& Marschner H (1991) Long and short-term effects of crop residues on aluminum toxicity, phosphorus availability and growth of pearl millet in an acid sandy soil. Plant Soil 136: 215-223

Lamers JPA \& Feil P (1993) The many uses of millet residues. ILEA Newsletter 9: 15 
Manu A, Bationo A \& Geiger SC (1991) Fertility status of selected millet producing soils of West Africa with emphasis on phosphorus. Soil Sci 152: 315-320

McClellan GH \& Notholt AJG (1986) Phosphate deposits of tropical sub-Saharan Africa. In: Mokwunye AU \& Vlek PLG (eds) Management of Nitrogen and Phosphorus Fertilisers of SubSaharan Africa, pp 173-223. Martinus Nijhoff, Dordrecht, The Netherlands

McIntire J \& Fussel LK (1986) On-farm experiments with millet in Niger. III. Yields and econimic analyses. ISC (ICRISAT Sahelian Center), Niamey, Niger

McIntire J, Bourzat D \& Pingali P (1992) Crop-livestock interactions in Sub-Saharan Africa. Washington, DC: The World Bank.

Michels K, Sivakumar MVK \& Allison BE (1995) Wind erosion control using crop residue: II. Effects on millet establishment and yield. Field Crops Res 40: 111-118

Padwick GW (1983) The maintenance of soil fertility in tropical Africa: A review. Expl Agric 19: 293-310

Penning de Vries FWT \& Djitèye MA (1982) La productivité des pâturages sahéliens. Une étude des sols, des végétations et de l'exploitation de cette ressource naturelle. Agric. Res. Rep. 918, PUDOC, Wageningen. $523 \mathrm{pp}$

Pieri C (1986) Fertilisation des cultures vivrières et fertilité des sols en agriculture paysanne subsaharienne. Agron Trop 41: 1-20

Pieri C (1989) Fertilité des terres de savane. Bilan de trente ans de recherche et de développement agricoles au Sud du Sahara. Ministère de la Coopération. CIRAD. Paris, France. 444 pp
Powell JM \& Mohamed Saleem (1987) Nitrogen and phosphorus transfers in a crop-livestock system in West Africa. Agric Syst 25: 261-277

Powell JM, Ikpé FN, Somda ZC \& Fernandez-Rivera S (1998) Urine effects on soil chemical properties and the impact of urine and dung on pearl millet yield. Expl Agric 34: 259-276

Rebafka F-P, Hebel A, Bationo A, Stahr K \& Marschner H (1994) Short- and long-term effects of crop residues and of phosphorus fertilization on pearl millet yield on an acid sandy soil in Niger, West Africa. Field Crops Res 36: 113-124

Sedogo MP (1993) Evolution des sols ferrugineux lessivés sous culture: influences des modes de gestion sur la fertilité. Thèse de Doctorat Es-Sciences, Abidjan, Université Nationale de Côte d'Ivoire

Stoorvogel J \& Smaling EM (1990) Assessment of soil nutrient depletion in sub-Saharan Africa: 1983-2000. Vol. 1, Main Report. The Winand Staring Center, Wageningen, The Netherlands

Williams TO, Powell JM \& Fernandez-Rivera S (1995) Manure utilization, drought cycles and herd dynamics in the Sahel: Implications for crop productivity. In: Powell JM, Fernandez-Rivera S, Williams TO \& Renard C (eds) Livestock and Sustainable Nutrient Cycling in Mixed Farming Systems of Sub-Saharan Africa, Vol. 2, pp 393-409. Technical Papers. Proceedings of an International Conference, 22-26 November 1993. International Livestock Centre for Africa (ILCA), Addis Ababa, Ethiopia 